\section{Lembaran Volume 16 Number 1 Sejarah April 2020}

\title{
Romantisme Kereta Angin (Sepeda Onthe/) di Yogyakarta Tahun 1970an
}

\author{
PUJI RAHAYU \\ Magister Sejarah, Universitas Gadjah Mada \\ Email: prahayu753@gmail.com
}

\begin{abstract}
This article examines the use of bicycle as public transport in the city of Yogyakarta during the 1970s. In the early years following Indonesian independence, the Indonesian society resumed its daily, peaceful life now with a new hope of economic and social prosperity as promised by the freedom from colonialism. In the city of Yogyakarta, the independent period of the 1970s was marked by the widespread use of bicycle as a public transport so immensely that the city got a reputation as a bicycle city. This article shows that while the widespread distribution of bicycle in Yogyakarta during the time was widespread, it still retained a social status. Bicycle was a symbol that erased colonialism as its use in the 1970s was not associated with the European elitism anymore. However, at the same time it showed a social chasm in the Yogyakarta society as only a small number of people, mostly government officials and university students, could afford it. In the 1970s city of Yogyakarta, bicycle functioned both as a symbol of freedom and as a mark of social divide.
\end{abstract}

\begin{abstract}
Abstrak
Penelitian ini berangkat dari tiga hal yang mendasar. Pertama, adanya sebutan Yogyakarta sebagai kota sepeda di tahun 1970an. Kedua, adanya peringatan harihari besar tertentu di Yogyakarta yang menggunakan sepeda onthel sebagai salah satu ikon, seolah ingin merepresentasikan kondisi masa lalu di Yogyakarta. Ketiga, hadirnya komunitas sepeda onthel di Yogyakarta sebagai salah satu wujud ketertarikan masyarakat terhadap alat transportasi sepeda onthel. Pokok permasalahan penelitian ini yaitu bagaimana Yogyakarta disebut sebagai kota sepeda di tahun 1970an serta bagaimana sebenarnya sepeda onthel difungsikan oleh masyarakat Yogyakarta. Sumber-sumber yang dipakai mencakup arsip, surat kabar, majalah, buku-buku yang berkaitan serta wawancara. Hasil penelitian menunjukkan bahwa sepeda onthel pada dasarnya menjadi alat transportasi istimewa masyarakat Yogyakarta di tahun 1950 hingga 1970-an. Sebutan Yogyakarta sebagai kota sepeda pada dasarnya layak dimiliki Yogyakarta di tahun 1970an. Selain itu, sepeda onthel memiliki beberapa fungsi sosial, di antaranya yaitu mampu memperluas hubungan interaksi antar masyarakat, menjadi sarana peningkatan ekonomi, sebagai simbol status sosial, memberi ruang kebebasan bagi perempuan, hingga akhirnya menjadi alat transportasi yang tersisihkan.
\end{abstract}

\section{Keywords:} 1970s; bicycle; public transport; social transformation; social history; Yogyakarta

Kata Kunci: 1970an; alat transportasi umum; sepeda onthel; perubahan sosial; sejarah sosial; Yogyakarta 


\section{Pendahuluan}

Citra Yogyakarta sebagai kota sepeda hanya menjadi sebuah cerita masa lalu (Kompas, 5 Februari 1970). Hal ini sangat berbeda dengan kondisi Yogyakarta saat ini. Kendaraan bermesin mendominasi jalanan di Yogyakarta. Namun, ingatan masyarakat akan kondisi jalanan Yogyakarta yang pernah didominasi oleh sepeda onthel seakan masih melekat. Adanya peringatan hari-hari besar tertentu di Yogyakarta yang menggunakan sepeda onthel sebagai salah satu ikon, menunjukkan ada sebuah kerinduan masyarakat terhadap keadaan Yogyakarta di masa lalu. Misalnya saja dalam peringatan serangan 1 Maret di titik $0 \mathrm{~km}$, terdapat beberapa orang yang menggunakan sepeda onthel lengkap dengan pakaian seragam militernya. ${ }^{1}$

Diungkapkan oleh salah seorang pimpinan Komunitas Sepeda Onthel Podjok, bahwa didirikannya komunitas sepeda onthel adalah salah satu wujud apresiasi masyarakat terhadap sepeda onthel yang pernah menjadi alat transportasi istimewa di masa lalu. ${ }^{2}$ Komunitas ini memiliki kegiatan rutin untuk melakukan konvoi sepeda onthel. Anggotanya terdiri dari berbagai kalangan masyarakat, dari yang berusia muda hingga tua.

\section{Kehadiran Sepeda Onthel di Yogyakarta}

Yogyakarta merupakan salah satu daerah yang menjadi pusat orang-orang Eropa di awal abad ke-20. Orang-orang Eropa memiliki pemukiman tersendiri. Pusatnya terletak di timur benteng kompeni yaitu bernama kampung Lodji Kecil. Di awal abad ke-20 orang-orang Eropa membuka daerah pemukiman baru di bagian utara kota, yaitu Kotabaru (Riyadi Gunawan \& Darto Harnoko, 2012: 10).

Diungkapkan oleh Robert Van Niel bahwa pada awal tahun 1900 kalangan Eropa yang berpendidikan baik dan berasal dari golongan menengah membawa serta kebudayaan barat yang kemudian membentuk suatu dunia barat di daerah perkotaan pulau Jawa (Robert van Niel, 1984: 2). Adanya pemukiman orang-orang Eropa tersebut membawa serta kebudayaan baru, yang pada akhirnya memberikan pengaruh terhadap orang-orang bumiputera.

Budaya menggunakan sepeda onthel merupakan salah satu bentuk pengaruh orang-orang Eropa dalam bidang transportasi. Tujuan utama dibawanya sepeda onthel ke tanah jajahan yaitu untuk memperlancar arus transportasi aparat militer Belanda. Selain itu, para misionaris seperti pastur juga menggunakan sepeda onthel sebagai alat transportasi (Hermany, 2010: 22).

1) Penulis melihat dengan sendiri beberapa orang yang mengendarai sepeda onthel pada peringatan serangan 1 Maret tahun 2014, kemudian sepeda onthel tersebut diparkir secara berjajar di pinggir jalan titik $0 \mathrm{Km}$ Yogyakarta pada pukul 06.00 pagi.

2) Wawancara dengan Bapak Towil, pimpinan komunitas sepeda Onthel Podjok Yogyakarta pada tanggal 5 September 2015 pukul 04.30, dijelaskan pula bahwa di dirikannya komunitas sepeda tersebut juga berawal dari sebuah keinginan untuk mengangkat kembali sepeda onthel yang pernah menjadi alat transportasi istimewa di masa lalu. 
Kata "Onthel" merupakan sebuah istilah yang berasal dari bahasa Jawa yang berarti putar, kayuh, genjot. Onthel pada awalnya digunakan untuk menyebut semua benda yang bergerak memutar. Namun, sebutan Onthel bagi orang Jawa sangat diidentikkan dengan sebuah alat transportasi sepeda tua, yang mana digerakkan oleh tenaga manusia dengan cara mengayuh. Setelah sepeda tersebut dikayuh, maka rodanya akan berputar. Kecepatan laju sepeda tergantung pada kecepatan kaki dari pengendaranya (Saimima, Sugianto, Anam dan Wiratman, 2015: 21).

Salah satu penemu sepeda yang dinilai cukup valid yaitu Baron Karl Drais pada tahun 1817. Baron Karl Drais yang pertama kali memperoleh Hak Paten atas sepeda temuannya pada tanggal 17 Februari 1818. Temuan ini pada dasarnya sudah dirintis sejak tahun 1812. Pada saat itu terdapat fenomena alam yang membuatnya bergegas meyempurnakan temuannya. Terdapatnya musim panas di Eropa tahun 1816 yang dikenal sebagai "musim tanpa matahari" menyebabkan wilayahnya terselimuti salju, sehingga ladang pertanian mengalami gagal panen. Kuda-kuda kesulitan mencari makanan, bahkan terjadi juga pada manusia. Alat transportasi kereta yang bergantung pada kuda pun terhenti. Itulah yang membuat Baron Karl Drais terobsesi menyempurnakan alat yang bergerak tanpa kuda yaitu sepeda (Ahmad Arif, 2010: 21).

Pada awalnya sepeda dikenal dengan nama draisine. Istilah ini diambil dari nama pencipta awalnya yaitu Baron Karl Drais. Selain itu juga dikenal sebagai Hobby Horse, disebut demikian karena merujuk pada kuda-kudaan yang pada waktu itu menggantikan tenaga kuda sebagai alat pengangkut. Penemuan alat ini merupakan titik awal dari sebuah sepeda modern, yang mana mulai dilengkapi beberapa komponen yang lebih sempurna. Komponen tersebut di antaranya dilengkapinya sebuah sepeda dengan pedal dan rantai (Ahmad Arif, 2010:21).

Sebutan sepeda onthel hanya terkenal di pulau Jawa. Selain istilah sepeda onthel, orang Jawa juga menyebutnya Pit Onthel. Kata Pit berasal dari kata Fiets, yang mana berasal dari bahasa Belanda Fietsen. Terdapat pula sebutan lain dari sepeda onthel, Masyarakat Sunda menyebutnya dengan istilah Sapedah yang mana berasal dari kata sepeda, sedangkan orang Aceh menyebutnya Keutangen/Keutanging yang berasal dari kata Kereta Angin.

Memiliki sebuah sepeda onthel selayaknya orang-orang Eropa merupakan salah satu impian orang-orang bumiputera. Namun, tidak semuanya mampu mewujudkan impian tersebut. Hanya kalangan kelas atas yang pada awalnya mampu memiliki sebuah sepeda onthel.

Sejak 1902 di Yogyakarta sudah berdiri sebuah toko sepeda bernama Wiriosoeseono. Toko ini menawarkan sepeda merk Elephant dan Norman, yang mana terletak di daerah Lodji Kecil. Harga sepeda saat itu ada yang empat belas ribu rupiah dan lima belas ribu rupiah. Untuk pemesanan sepeda 
buatan luar negeri harus menunggu selama lima hari. Hal ini dikarenakan saat itu pengangkutannya harus melalui kapal laut (BPAD DIY, Arsip Jawatan Pekerjaan Umum no. 2691). ${ }^{3}$

Terdapat pula sebuah toko sepeda bernama HWA di Toegoe Kidoel no 119 Djogja. Toko ini sudah berdiri sejak tahun 1938 (Soeara Mataram, 1938: 5). Selain itu juga ada toko sepeda bernama Sien Hok Hien, yang terletak di Toegoe Koelon nomor 76 Yogyakarta. Toko ini tidak hanya menawarkan sepeda onthel baru, melainkan juga sebagai tempat reparasi (Soeara Mataram, 15 November 1937). Masih terdapat beberapa toko sepeda onthel lainnya di Yogyakarta selain toko-toko di atas. Sebagian besar toko itu milik orangorang China, hal ini sangat terlihat dari nama-nama tokonya. Meskipun demikian, hanya sebagian kecil golongan bumiputera yang mampu membeli sepeda onthel dari toko-toko tersebut.

Sepeda onthel adalah alat transportasi yang memiliki harga cukup tinggi, terutama pada masa sebelum kemerdekaan. Khusus untuk sepeda onthel merk Eropa seperti Gazelle, Simplex, dan Raleigh dan sejenisnya. Harga satu buah sepeda onthel sebanding dengan harga tiga ton beras. ${ }^{4} \mathrm{Hal}$ ini menjadi salah satu sebab tidak semua kalangan masyarakat mampu membeli sepeda onthel. Hanya kalangan atas yang mampu memiliki sebuah sepeda onthel buatan Eropa.

Seperti halnya yang diungkapkan oleh salah seorang keluarga keraton bernama K.R.T Purwodiningrat, bahwa pihak keraton pernah diberi beberapa sepeda onthel oleh orang-orang Eropa. ${ }^{5} \mathrm{Hal}$ ini membuktikan bahwa golongan bangsawan memang lebih dulu memiliki sepeda onthel buatan Eropa.

Pernyataan tersebut dibuktikan dengan adanya beberapa surat pembayaran pajak sepeda onthel dari pihak keraton. Pada tahun 1947 keluarga keraton sudah menggunakan sepeda onthel sebagai sarana transportasi. Hal ini terbukti ketika pihak kraton memberitahukan kepada kepala kantor pajak kotapradja Yogyakarta mengenai sepeda-sepeda yang tidak dikenakan pajak. Beberapa sepeda itu di antaranya merk Serva, Simplex, Eagle, Opel, Dunlop, Groesco, Insulinde, Rover (Arsip Keraton Ngayogyakarta Hadiningrat no. 4183. 49/HP/C-VI/7).

Adanya surat perintah dari B.P.H. Prabuningrat kepada kepala kantor pajak juga membuktikan bahwa pihak kraton telah memiliki sepeda onthel. Surat tersebut menjelaskan bahwa pihak kraton memberi utusan kepada salah

3) Mengenai penawaran sepeda onthel dari sebuah toko di Yogyakarta bernama Wiriosoeseno kepada kepala Biro Penyelenggara Sekretariat P.P.d I.DIJ di Kepatihan tertanggal 16 November 1970.

4) Wawancara dengan Bapak Wagiman, tanggal 05 November 2016, pukul 13.23, pemilik bengkel sepeda onthel di Desa Pleret, Kecamatan Pleret, Kabupaten Bantul sejak tahun 1950

5) Wawancara dengan KRT Purwodiningrat tanggal 18 Juli 2016, pukul 11.00, salah seorang keluarga Keraton di perpustakaan Widyo Budoyo Keraton Yogyakarta 
seorang abdi dalem untuk mengambil plombir sebanyak sebelas biji. Plombir tersebut akan segera ditempel di sepeda-sepedanya, di antaranya sepeda onthel bermerk Phillips, Burgers, Mansonia, dan Gloria. Dalam surat ini disertakan nomor seri dari masing-masing sepeda onthel yang telah dilakukan pajak (Arsip Keraton Ngayogyakarta Hadiningrat no. 4183, 49/HP/C-VI/7).

Hal ini menunjukkan bahwa pihak keraton lebih dulu memiliki sepeda onthel. Pada tahun 1950 sebagian masyarakat biasa di Yogyakarta mulai mampu memiliki sepeda onthel. Ini terlihat dari beberapa bukti pembayaran para pegawai pemerintahan di Yogyakarta. Diungkapkan oleh seorang tukang bengkel sepeda onthel di Desa Pleret bernama Wagiman bahwa selain pegawai pemerintah, pada tahun 1950an golongan masyarakat kecil seperti petani dan pedagang sudah mulai memiliki sepeda onthel. Namun, jenis sepeda yang mereka gunakan tidak seperti yang digunakan oleh golongan kelas atas. Petani dan pedagang belum mampu untuk membeli sepeda onthel merk Gazelle ataupun Simplex. ${ }^{6}$

\section{Bagaimana Masyarakat Yogyakarta mampu memiliki Sepeda Onthel?}

Pada tahun 1950 mayoritas masyarakat Yogyakarta sudah mulai menggunakan sepeda onthel sebagai alat transportasi. Pengguna sepeda onthel sebagian besar para pegawai kantor pemerintahan di Yogyakarta. Para pegawai mampu memiliki sepeda onthel dengan cara menerima subsidi dari pemerintah daerah Yogyakarta. Pada tahun 1950an terdapat beberapa bukti laporan cicilan angsuran oleh para pegawai untuk pembayaran sepeda onthel.

Terdapat beberapa pegawai jawatan Sosial bagian kesehatan rakyat yang sudah memiliki sepeda onthel pada tahun 1950, di antaranya yaitu dr. K.R.T. Dirdjohusodo, Karsimin sebagai mantri juru rawat, Girah sebagai bidan, Sujatinah sebagai mantri juru rawat (BPAD DIY, Arsip Jawatan Pemerintahan Umum No. 3845). Hal ini membuktikan bahwa seorang dokter di jawatan sosial saat itu juga menggunakan sepeda onthel. Bahkan mantri juru rawat dan bidan juga diberikan sepeda onthel sebagai alat transportasi saat itu.

Selain itu, juga terdapat beberapa pegawai dari jawatan Pekerjaan Umum yang memiliki sepeda onthel. Di antaranya yaitu R.P. Kartironosumartojo, S. Senoseputro, R.Ng. Sindupurnomo, R.P. Kartidirdjoseputro, R.M. Subari, R.P. Kartiwidjojo, Salikin, R.M. Kurupatkin, R.M. Sumowidagdo, R.P. Kartipurwanto, R.Ng. Kartisastrowidagdo, R. Suratman, S. Ismartojo, Ng. Kartisudijono, Suradji (BPAD DIY, Arsip Jawatan Pemerintahan Umum no. 3845).

Pemilik sepeda tersebut telah melunasi pembayaran sepeda kepada

6) Wawancara dengan Bapak Wagiman, tanggal 05 November 2016, pukul 13.23 di Desa Pleret, Kecamatan Pleret, Kabupaten Bantul. 
pihak jawatan keuangan. Dari daftar nama-nama pegawainya menunjukkan bahwa pemilik sepeda onthel di jawatan Pekerjaan Umum sebagian besar adalah seorang Raden. Hal ini terlihat dari gelar yang tertulis didepan namanama mereka. Dengan demikian, sebagian pemilik sepeda onthel adalah golongan priyayi yang masih keturunan Raden Mas, Raden Patih, dan Raden Ngabehi.

Di Jawatan Pradja terdapat nama-nama pegawai yang terdaftar dalam pembagian sepeda onthel, yaitu R.P. Prodjomandojo, R.P. Bedjo, R.P. Prodjo Puworo, R.P. Prodjo Malaja. Begitu pula di kantor Jawatan Kemakmuran, ada beberapa pegawai yang mendapatkan sepeda onthel. Mereka sebagian besar juga bergelar Raden. Di antaranya yaitu R.W. Prodjosewojo, R.W. Dirdjodiprodjo, R.Wg. Dirjowirjogati (BPAD DIY, Arsip Jawatan Pemerintahan Umum no. 3842).

Dari beberapa nama pemilik sepeda di kantor Jawatan Pemerintahan DIY, menunjukkan bahwa sepeda onthel yang mereka miliki terdiri dari berbagai merk. Di antaranya yaitu sepeda merk Raleigh, Tuscon, Rambler, Phillips, Sunbeam, Norman, Hercules. Harga masing-masing sepeda onthel rata-rata $150-200 \mathrm{f}$.

Pada tahun 1952 Dewan Perwakilan Daerah Istimewa Yogyakarta membagikan seribu sepeda onthel kepada seluruh pegawai pemerintahan di DIY. Tujuan diberikannya subsidi yaitu untuk memperlancar kegiatan operasional pemerintahan, khususnya bagi para pegawai yang membutuhkan perjalanan dinas. Pembagian sepeda tidak semata-mata diberikan langsung kepada para pegawai, mereka diwajibkan membeli sepeda tersebut dengan sistem kredit. Setiap pegawai wajib mengangsur setiap bulannya melalui potongan gaji.

Dari seribu sepeda onthel yang dibagikan kepada para pegawai tersebut, enam ratus sepeda onthel khusus untuk pegawai yang sering melakukan tourne atau perjalanan dinas. Sedangan empat ratus sepeda onthel untuk pegawai yang tidak bertourne namun dipandang membutuhkan sepeda onthel. Ada beberapa tingkatan harga sepeda onthel saat itu, yang mana sepeda onthel kelas I harganya delapan ratus rupiah, sepeda onthel kelas II seharga enam ratus rupiah, dan sepeda onthel kelas III seharga empat ratus lima puluh rupiah (BPAD DIY, Arsip Jawatan Pemerintahan Umum no. 3847).

Para pegawai yang telah diberi pinjaman uang wajib mengembalikan dengan cara angsuran tiap bulan. Pengembalian tersebut selambat-lambatnya empat puluh bulan untuk pembelian sepeda kumbang, enam puluh bulan untuk pembelian sepeda motor dan mobil. Apabila pegawai yang bersangkutan meninggal dunia karena kecelakaan pada waktu menggunakan kendaraankendaraan tersebut maka pinjaman uang akan dihapuskan atau dibebaskan dari angsuran.

Dari subsidi yang telah diberikan pemerintah DIY tersebut dapat 
diketahui bahwa bentuk subsidi berupa bantuan kredit. Pemerintah DIY tidak secara langsung memberikan sepeda onthel, melainkan memberikan kemudahan bagi para pegawai untuk memiliki sepeda onthel.

Tidak semua golongan masyarakat mampu memiliki sepeda onthel dengan mudah. Hal ini terbukti dengan adanya beberapa kasus pencurian di Yogyakarta.

Tabel 1. Jumlah Kasus Pencurian Sepeda Onthel di DIY tahun 1975-1976

\begin{tabular}{cc}
\hline Kotamadya / Kabupaten & Jumlah Sepeda Onthel yang dicuri \\
\hline Kota Yogyakarta & 95 \\
Bantul & 161 \\
Sleman & 187 \\
Gunung Kidul & 11 \\
Kulonprogo & 72 \\
\hline
\end{tabular}

Sumber: Laporan Sekretariat Ketertiban Umum DIY tahun 1975-1976 (BPAD)

Terdapatnya kasus pencurian menunjukkan bahwa sepeda onthel termasuk barang yang memiliki nilai tinggi di kalangan masyarakat. Pedagang dan Petani di Yogyakarta merupakan golongan masyarakat yang memiliki kelas sosial di bawah golongan priyayi kraton dan pegawai pemerintahan. Namun, Pedagang sendiri terbagi menjadi golongan pedagang besar dan pedagang kecil. Pedagang besar biasanya masuk dalam golongan masyarakat kelas atas, namun untuk pedagang kecil di anggap sebagai golongan kelas bawah atau Wong Cilik. Begitu pula dengan petani, ketika seorang petani memiliki lahan pertanian yang luas maka mereka masuk dalam golongan kelas atas. Akan tetapi untuk petani yang hanya menggarap sawah milik orang lain ataupun bekerja sebagai buruh pertanian, maka termasuk dalam golongan Wong Cilik.

Pedagang dan petani yang dimaksud dalam penelitian ini yaitu pedagang dan petani kecil. Sebelum tahun 1950, pedagang dan petani di Yogyakarta hanya berjalan kaki untuk melakukan aktivitas. Sepeda hanya dimiliki oleh para Kepala Desa ataupun para Pastur. Para pedagang dan petani tidak mampu untuk membeli sebuah sepeda onthel Gazelle. Harga sepeda Gazelle saat itu senilai 3 ton beras. ${ }^{7}$ Namun, setelah tahun 1950 sudah mulai ada pedagang dan petani kecil yang memiliki sepeda onthel. Bahkan anak-anak sekolah di Bantul yang sudah mulai menggunakan sepeda onthel. Sepeda onthel saat itu dianggap sebagai alat Sambung Laku.

Pedagang dan petani membeli sepeda onthel bukan dari toko sepeda yang bersertifikat, melainkan hanya dari bengkel-bengkel sepeda yang berupa

7) Wawancara dengan Bapak Wagiman, tanggal 05 November 2016, pukul 13.23, Pemilik Bengkel sepeda onthel di Desa Pleret, Kecamatan Pleret, Kabupaten Bantul sejak tahun 1950 . 
sepeda onthel rakitan sendiri. Salah seorang pedagang sepeda onthel di pasar Barongan, Bantul menyebutkan bahwa pada tahun 1950-an ada beberapa pedagang sepeda onthel yang merangkainya sendiri, karena dianggap lebih laku di pasaran. ${ }^{8}$ Selain harganya yang lebih murah dari Gazelle dan Simplex, para pedagang dan petani beranggapan bahwa fungsi utama memiliki sepeda yaitu sebagai alat transportasi ke pasar dan bisa mengangkut barang.

Dari keterangan di atas menunjukkan bahwa sebelum tahun 1950an para pedagang dan petani di Yogyakarta belum mampu membeli sepeda onthel. Mereka mulai bisa membelinya setelah tahun 1950, yang mana jenis sepeda onthel yang digunakan saat itu hanyalah sepeda onthel hasil rakitan. Sepeda Gazelle masih dianggap sebagai barang mewah yang hanya mampu dibeli oleh golongan kelas atas.

\section{Yogyakarta menjadi " Kota Sepeda"}

Kota sepeda dapat didefinisikan sebagai sebuah kota dimana sebagian besar penduduk yang tinggal pada kota tersebut memiliki tingkat aktivitas yang cukup tinggi dalam penggunaan sepeda. Beberapa kota di dunia yang mendapat julukan kota sepeda pada umumnya memiliki beberapa beberapa kriteria khusus, di antaranya yaitu sebagian besar dari jumlah penduduk kota tersebut menggunakan sepeda sebagai alat transportasi sehari-hari, kota tersebut memiliki komunitas sepeda yang cukup aktif dan besar, kota tersebut memiliki wisata bersepeda.

Yogyakarta dan sepeda onthel merupakan dua hal yang tidak dapat dilepaskan. Sebutan Yogyakarta sebagai kota sepeda seakan melekat kuat di kalangan masyarakat. Namun, tidak sedikit yang mengetahui alasan mengapa kota Yogyakarta bisa disebut sebagai kota sepeda pada tahun 1950-1970-an, bagaimana masyarakat mampu memilikinya serta bagaimana sepeda onthel saat itu difungsikan. Salah satu barang yang diimpikan masyarakat Yogyakarta di tahun 1950-an yaitu sepeda onthel. Namun, tidak semua masyarakat mampu memilikinya dengan mudah. Hanya golongan-golongan tertentu yang mampu membeli sepeda onthel di tahun 1950-an.

Citra Yogyakarta sebagai "Kota Sepeda" di tahun 1950-1970-an memang sangat melekat. Hal ini dibuktikan dengan adanya jumlah pengendara sepeda onthel yang tinggi di kalangan masyarakat (Lihat tabel 1).

Berdasarkan laporan pada tabel 1 dapat diketahui bahwa pada tahun 1970-an pengguna sepeda onthel menempati posisi tertinggi jika dibandingkan dengan pengguna kendaraan tidak bermotor lainnya. Hal ini menunjukkan bahwa pada dasarnya julukan Yogyakarta sebagai kota sepeda memang benar. Selisih jumlah kepemilikan sepeda jika dibandingkan dengan kendaraan lain sangatlah berbeda jauh.

8) Wawancara dengan bapak Sumianto, tanggal 05 November 2016, pukul 12.30, salah seorang pedagang sepeda onthel di Pasar Barongan, Bantul. 
Tabel 2. Jumlah Kendaraan tidak Bermotor di DIY Tahun 1972-1978

\begin{tabular}{cccccc}
\hline Tahun & Becak & Andong & Gerobak & Keseran & Sepeda \\
\hline 1972 & 4.925 & 1.041 & 806 & 107 & 165.640 \\
1973 & 3.989 & 1.486 & 958 & 119 & 175.136 \\
1974 & 4.935 & 1.511 & 1.539 & 330 & 216.265 \\
1975 & 5.607 & 1.315 & 936 & 153 & 227.482 \\
1976 & 4.884 & 1.102 & 956 & 140 & 192.473 \\
1977 & 5.668 & 1.272 & 1.187 & 231 & 238.466 \\
1978 & 5.936 & 1.253 & 1.209 & 243 & 251.663 \\
\hline
\end{tabular}

Sumber: Direproduksi dari Laporan D.L.L.A.J.R, Badan Pusat Statistik Daerah Istimewa Yogyakarta,Tahun 1972-1978.

Selain terlihat dari jumlahnya, juga terlihat beberapa foto yang merepresentasikan kondisi jalanan di Yogyakarta tahun 1950-1970-an. Terdapat beberapa jalan di Yogyakarta yang ramai dengan pengendara sepeda onthel. Mulai tahun 1948 pada dasarnya masyarakat Yogyakarta sudah mampu memiliki sepeda onthel. Namun, pada tahun 1950 menjadi titik awal dimana kalangan masyarakat Yogyakarta menjadikan sepeda onthel sebagai alat transportasi utama sehari-hari.

Adanya permintaan Plombir yang tinggi juga menjadi salah satu bukti bahwa Yogyakarta layak mendapat sebutan sebagai Kota Sepeda. Plombir merupakan sebuah lempengan timah yang wajib ditempelkan di sepeda onthel, yang mana sebagai bukti bahwa pemilik sepeda onthel tersebut sudah melakukan pajak. Apabila sepeda onthel tidak ada plombirnya, maka pemilik akan dikenakan sebuah sanksi pelanggaran. Adanya permintaan plombir yang tinggi di Yogyakarta juga menjadi salah satu bukti bahwa pemilik sepeda onthel di Yogyakarta juga tinggi (BPAD DIY, Laporan Sekretariat Pemerintah DIY).

Selain itu, adanya beberapa bukti penarikan pajak juga membuktikan bahwa pada tahun 1950-1970-an di Yogyakarta sepeda onthel mempunyai arti penting bagi masyarakat. sepeda menjadi salah satu barang yang memiliki nilai tinggi, sehingga harus dilakukan pembayaran pajak. Penarikan pajak dilakukan oleh seorang pemungut pajak, yang mana akan mendapatkan upah pungut atau colekteloon. Seperti halnya yang dijelaskan oleh Hermanu dalam bukunya Simplex Ngganggo Berko bahwa di Yogyakarta sering ada "cegatan" sepeda onthel. Cegatan biasanya dilakukan pada pagi hari, dimana banyak orang berangkat ke kantor atapun ke sekolah. Terdapat beberapa siswa yang sering melakukan kecurangan apabila terkena cegatan, mereka membagi plombir menjadi beberapa bagian lalu ditunjukkan ke petugas hansip atau perangkat desa yang bertugas memeriksa sepeda onthel. Hal ini dilakukan karena ada beberapa dari mereka yang belum melakukan pajak, sehingga tidak memiliki plombir atau tanda bukti pajak (Hermanu 2013: 90). 
Besarnya tarif pajak dari masing-masing sepeda onthel tidak sama. Namun, Pemerintah Yogyakarta menetapkan bahwa pemilik sepeda onthel maupun kendaraan tidak bermotor lainnya wajib membayar pajak sebesar 50 persen dari tarif yang telah ditentukan. Dari masing-masing jenis sepeda onthel memiliki standart tarif yang berbeda-beda, tergantung dari jenis sepedanya. Sedangkan besarnya upah pungut atau colekteloon yaitu 10 persen dari besarnya penarikan pajak (BPAD DIY, Arsip Jawatan Pemerintahan Umum no. 63).

Penetapan pajak tersebut sudah ada sejak tahun 1953, yang mana tercantum dalam Peraturan Daerah Istimewa Yogyakarta Nomor 1 tahun 1953 dan Peraturan Daerah Istimewa Yogyakarta Nomor 6 tahun 1954. Namun, pada tahun 1972 peraturan tersebut dianggap tidak sesuai lagi dengan kondisi ekonomi masyarakat Yogyakarta. Maka dari itu diadakan sebuah rapat pleno oleh DPRD Bantul pada tanggal 22 Agustus 1972 untuk melakukan beberapa perubahan dari peraturan yang sudah ada.

Beberapa perubahan tersebut di antaranya mengenai sanksi bagi pemilik kendaraan tidak bermotor yang belum melakukan pajak. Berdasarkan peraturan sebelumnya, sanksi bagi pemilik kedaraan tidak bermotor yang belum melakukan pajak yaitu 15 hari penjara atau denda sebesar dua ribu lima ratus rupiah. Namun, sanksi ini dianggap terlalu berat bagi pemilik kendaraan tidak bermotor. Berdasarkan hasil keputusan dari rapat pleno DPRD Bantul, sanksi diubah menjadi 7 hari penjara atau denda sebesar seribu rupiah.

Seiring meningkatnya jumlah mahasiswa yang menempuh pendidikan di Yogyakarta juga sangat mendukung pertambahan jumlah pengendara sepeda di jalanan. Pada tahun 1975 kurang lebih 20.769 mahasiswa melakukan pendaftaran di UGM (Kedaulatan Rakyat, 3 Januari 1975). Hal ini sangat dimungkinkan juga menjadi salah satu faktor pendukung Yogyakarta mendapat sebutan sebagai Kota Sepeda. Sepeda onthel bukan lagi menjadi sebuah simbol status sosial, melainkan sebagai sarana transportasi para mahasiswa dan pelajar di Yogyakarta.

Ketika Hindia Belanda dikuasai oleh orang-orang Eropa, wanita pribumi pada awalnya dilarang naik sepeda. Hal ini dianggap tidak pantas, karena sepeda onthel hanya menjadi milik wanita-wanita Belanda. Namun, setelah awal abad 20 sudah ada beberapa wanita pribumi yang memakai sepeda onthel (Saimima, Sugianto, Anam dan Wiratman, 2015: 40). Keberadaan sepeda onthel mampu menciptakan sebuah ruang baru bagi kaum perempuan. Dengan adanya sepeda onthel maka banyak perempuan yang mampu bepergian ke sekolah, ke kantor, dan tempat-tempat lainnya.

Terlihat para perempuan muda di Yogyakarta yang menggunakan sepeda onthel dengan mengenakan pakaian seperti perempuan-perempuan Belanda. Hal ini terjadi pada tahun 1952. Bahkan perempuan tersebut sudah berani berboncengan dengan lawan jenis. Hal ini menunjukkan bahwa sepeda 
onthel pada dasarnya memberi ruang kebebasan untuk kalangan perempuan muda di Yogyakarta (Kedaulatan Rakyat, 25 Januari 1952).

Kondisi ini tidak berlangsung lama, sejak hadirnya sepeda motor di Yogyakarta maka masyarakat beralih dari sepeda onthelnya. Kemudahan sistem kredit kendaraan bermotor mendorong masyarakat lebih memilih sepeda motor. Keberadaan sepeda onthel di Yogyakarta semakin terpinggirkan di tahun 1980an. Sepeda bukan lagi dianggap sebagai salah satu penunjang prestise sosial dan simbol pembeda kelas, melainkan hanya sebuah alat transportasi bagi para petani di pedesaan.

\section{Kesimpulan}

Sepeda onthel pada dasarnya memang benar menjadi alat transportasi istimewa masyarakat Yogyakarta di tahun 1970-an. Sepeda onthel menjadi alat transportasi yang mendominasi jalanan di Yogyakarta. Hal ini terlihat dari segi jumlah kepemilikan sepeda onthel oleh masyarakat Yogyakarta saat itu. Namun, tidak semua golongan masyarakat dapat memilikinya dengan mudah. Adanya beberapa kasus kejahatan terhadap pemilik sepeda onthel pada tahun 1970-an sebagai salah satu bukti ketidakmampuan masyarakat untuk memiliki sepeda onthel. Golongan kelas atas lebih dahulu memiliki sepeda onthel jika dibandingkan dengan golongan kelas bawah. Namun, citra Yogyakarta sebagai kota sepeda tidak bertahan selayaknya citranya sebagai kota pendidikan. Keberadaannya semakin menurun ketika kendaraan bermotor mulai mendominasinya.

\section{Referensi}

\section{Buku}

Ahmad Arif. Melihat Indonesia Dari Sepeda. Jakarta: Kompas, 2010.

Fahmi Saimima, Sugianto, Choirul Anam, H.P Wiratraman. Onthel (Sejarah, Budaya, \& Edukasi). Jakarta: Nagoya, 2015.

Riyadi Gunawan \& Darto Harnoko. Mobilitas Sosial Daerah Istimewa Yogyakarta Periode Awal Abad ke-20: Suatu Kajian Sejarah Sosial. Yogyakarta: Ombak, 2010. Hermanu. Pit Onthel 2010 Indische Fietsen. Yogyakarta: Bentara Budaya, 2010. Selo Sumardjan. Perubahan Sosial Yogyakarta. Jakarta: Komunitas Bambu, 2009. Van Niel, Robert. Munculnya Elite Modern Indonesia. Jakarta: Pustaka Jaya, 1984.

\section{Koran}

Kedaulatan Rakyat, 3 Januari 1975 “Tahun 1975 Minat Menjadi Mahasiswa di Yogya Makin Besar”.

Kedaulatan Rakyat, Jumat 25 Januari 1952. "Kawanku Terbuka Pula bagi Putraputri”.

Kompas, 5 Februari 1970. "Kota Sepeda".

Soeara Mataram, 15 Januari 1938. "Toko HWA".

Soeara Mataram, 15 November 1937. "SIEN HOK HIEN". 


\section{Arsip}

BPAD DIY, Arsip Jawatan Pekerjaan Umum nomor 2691, yang berisi Tentang Surat penawaran sepeda onthel dari sebuah toko Di Yogyakarta bernama Wiriosoeseno kepada kepala Biro Penyelenggar Sekretariat P.P.dI.DIJ di Kepatihan tertanggal 16 November 1970.

BPAD DIY, Arsip Jawatan Pemerintahan Umum nomor 3845 tentang Surat Kontrak pemberian sepeda onthel dari Djawatan Sosial DIY kepada Kepala Djawatan Keuangan DIY, tertanggal 10 Juni 1950.

BPAD DIY,Arsip Jawatan Pemerintahan Umum nomor 3845 tentang Pengembalian surat kontrak dari djawatan keuangan DIY kepada pegawai-pegawai jawatan Pekerjaan Umum yang telah lunas pembayaran sepedanya, tertanggal 2 Mei 1951.

BPAD DIY, Arsip Jawatan Pemerintahan Umum nomor 3842 tentang Daftar yang mendapatkan pembagian sepeda onthel. Tertanggal 4 November 1950.

BPAD DIY, Arsip Jawatan Pemerintahan Umum nomor 3847 tentang surat Rencana pembagian sepeda kepada pegawai pemerintahan DIY dengan atas nama pengusul Dr. Sahir Nitimihardjo tertanggal 5 Februari 1952.

BPAD DIY, Arsip Jawatan Pemerintahan Umum nomor 63 tentang hasil rapat Pleno DPRD Bantul mengenai penetapan Pajak Kendaraan Tidak Bermotor di wilayah Yogyakarta, tertanggal 22 Agustus 1972.

Perpustakaan Widyo Budoyo, Arsip Kraton Ngayogyakarta Hadiningrat (masa Sri Sultan HB IX Tepas Halpita-Pura) nomor 4181 tentang surat nomor 167.H P/C-VI-8 mengenai pemberitahuan daftar nama-nama merk dan nomor sepeda yang dipakai untuk dinas di kantor-kantor kraton Yogyakarta dan bebas pajak untuk sepeda-sepeda tersebut, tertanggal 17 September 1947.

Perpustakaan Widyo Budoyo, Arsip Kraton Ngayogyakarta Hadiningrat (masa Sri Sultan HB IX Tepas Halpita-Pura) nomor 4183 tentang surat nomor 49/H.P/ $\mathrm{C}-\mathrm{VI} / 7$ dari kagungan dalem Tepas Hapitapura kepada Pengageng kantor padjak kotapradja Yogyakarta mengenai Plombir (pajak) sepeda tahun 1955.

Badan Pusat Statistik DIY, Laporan D.L.L.A.J.R Daerah Istimewa Yogyakarta tahun 1972-1978.

\section{Internet}

https://www.kamusbesar.com/asah-asih-asuh, diakses tanggal 05 Juni 2017 pukul 16.00 .

\section{Wawancara}

Wawancara dengan Bapak Towil, pimpinan komunitas sepeda Onthei Podjok Yogyakarta pada tanggal 5 September 2015 pukul 04.30.

Wawancara dengan Bapak Wagiman, tanggal 05 November 2016, pukul 13.23, pemilik bengkel sepeda onthel di Desa Pleret, Kecamatan Pleret, Kabupaten Bantul sejak tahun 1950.

Wawancara dengan KRT Purwodiningrat tanggal 18 Juli 2016, pukul 11.00, salah seorang keluarga Keraton di perpustakaan Widyo Budoyo Keraton Yogyakarta.

Wawancara dengan bapak Sumianto, tanggal 05 November 2016, pukul 12.30, salah seorang pedagang sepeda onthel di Pasar Barongan, Bantul. 